(c) 1986 ISIJ

\title{
「融体精鍊反応の物理化学とプロセス工学」 シンポジウム報告
}

\author{
Report of Symposium on "Physical Chemistry and Process \\ Engineering of Steelmaking Reactions"
}

Kazumi MORI

\section{1.はじめに}

融体精錬反応部会は鉄鋼基礎共同研究会の一つの研究 部会として昭和 55 年度に設立され，製鋼におけるスラ グー溶鉄間反応に関する研究を行い, 昭和 59 年度で研 究活動を終了した。部会の研究の成果のまとめとして昭 和 60 年 5 月に報告書「融体精錬反応の物理化学とプロ セス工学」を出版するとともに, 同 6 月 13 日， 14 日 の両日にわたり同名のシンポジウムを開催した。本稿は シンポジウムの発表討論の概要を報告するものである が，このシンポジウムが 5 年にわたつた部会の研究活動 の総仕上げという意味が大きいことから，はじめに部会 の設立と研究経過の概要を述べておく.

製鋼の分野では, オイルショック後 70 年代の後半か ら新しい技術開発に向けての動きが急にあわただしくな つた.これは基本的には資源・エネルギー・環境問題か らきたもので，とくに排出スラグの処理の問題や鋼の材 質に対する要求が厳しくなつた事態を背景として, 溶銑 予備処理, 転炉の複合吹錬, さらに取鍋精錬による溶鋼 処理に関し新しい技術開発の研究が活発に行われるよう になつた。これに関連し，会社関係において実際のプロ セスを構成する反応系を対象としたスラグー溶鋼間の分 配の測定や吹込精錬の研究が行われるようになつたが, さらに基礎にまでさかのぼつた研究が必要とされるよう になつた。

一方, 大学関係でもスラグ基礎系の熱力学的性質やス ラグー溶鉄間反応の平衡論的 ·速度論的研究, またプロ セス工学的研究が着実に続けられてきていたが，さらに 実際面からの強い刺激を受け，また実際問題と関連した 形で研究課題を見值し，昖大してゆこうといら気運にあ つた。

以上のような製鋼の実際技術開発の事情や製鋼反応の 基礎研究の流れを反映し, 鉄鋼基礎共同研究会運営委員 会において製鋼プロセスを追求するための基礎になる研 究を行うという趣旨の「融体異相間反応 (仮題)」(部会
長 森 一美）がとりあげられ，この部会を昭和 55 年 度より発足させることが昭和 54 年 12 月 3 日の同運営 委員会において決定された.

この部会の発足は製鋼反応の研究の現状からみて時宜 を得たものであつたが，研究分野がかなり広いこともあ り具体的な研究内容は部会設立準備の段階での検討にゆ だねられた。このため部会活動に先立ち準備会を開催 し，部会名を「融体精鍊反応」部会とすることをきめ， その研究内容につき協議した。 この中で, 溶鋼の脱りん の問題，転炉や取鍋精鍊における反応の平衡や筧拌の役 割など種々の問題が提起された。この検討のほか，関係 者へのアンケートもとり, 結局本部会ではスラグー溶 鉄 間反応の反応特性を基礎と実際の立場から研究するとい ら方向をらちだし，昭和 55 年 7 月 11 日第 1 回「融体 精錬反応」部会を開いた。

本部会の方針とした研究内容は便宜上つぎの二つに大 別される.

（1）スラグ-溶鉄間反応の平衡論的 · 速度論的研究 部会の重点テーマの一つで，とくに脱りんを中心的な 反応としてとりあげることとし, 実際技術の進歩, 変化 に対応して広い範囲の温度, 塩基度, 酸素ポテンシャル におけるスラグや特殊成分のスラグについての熱力学的 数值を求めることが要望された。一方, 速度論的研究に おいてはスラグー溶鉄間脱りん，脱硫反応の速度論，物 性·界面現象之の関係，反応の律速機構の解明を行う.

（2）スラグー溶鉄間精錬反応のプロセス工学的研 究 製鋼における浴内擤拌の重要性から，ガス吹き込みに おける浴内の流動状態の解析, 靦拌強度の表し方を検討 し，定式化することが課題として出された．浴に与えら れる攪拌動力と物質移動速度の関係や，スラグー溶 鉄 接 触法（粉体吹き込みその他）と反応進行度の関係も解明 してゆく，さらに各製鋼プロセスにおけるスラグーメタ ル間反応の反応特性の研究として, 溶銑予備処理, 取鍋 精鍊に拈けるフラックスの反応性を定量的に表示し，温 度や酸素ポテンシャルとの関係を明らかにすること, 転

昭和 60 年 8 月 26 日受付 (Received Aug. 26，1985) (依頼技術資料)

* 名古屋大学工学部 I博 (Faculty of Engineering, Nagoya University, Furo-cho Chikusa-ku Nagoya 464) 
炉精錬にお打るスラグー溶鋼間の分配比と㩭拌の関係を 図示, 数式化などで明らかにしてゆく.

以上の方針のもとに, 部会活動として各委員から提出 された資料をもとにして討論するといら形で研究を進め た. 初年度を除き年 4 回, 昭和 60 年 1 月 21 日を最後 として 19 回の部会を開催し,この間の提出資料は実に 130 件に達し, 活発な発表討論が行われた。途中で中間 のとりまとめを行い，鉄と鋼，69 (1983)，15， p. 242 に中間報告を行つた，部会の研究成果は報告書のとおり であるが，とくにスラグの熱力学的性質やスラグー溶鉄 間反応の平衡論的基礎研究, 製鋼技術開発の実際を反映 して溶銑予借処理に和けるスラグー溶鉄間反応特性につ いては多くの発表討論が行われた. なかでも, 本部会で 重点を拉いたりん反応について基礎から実際をでの広い 範围の研究が行われ，多くの成果が得られた。このほ か, 浴内流動やスラグーメタル間反応系における物質移 動や反応モデルによるプロセス解析, 転炬における反応 機構, 特殊フラックスの反応性などにつき新しい知見が 示されている.

シンポジウムでは時間がきわめて限られていたことも あり, 部会の研究成果全体についての発表討論を行らこ とはできなかつたが， 26 名の全部の部会委員または委 員代理の方々からよく工夫された発表をいただくことが できた.シンポジウムはつぎの 4 セッションにわけて行 い, セッションごとに総括的討論を行つた.

（1） スラグ-溶鉄間反応の熱力学

（2） スラグー溶鉄間反応の速度論

（3）溶銑処理汇打计る反応特性

（4）転炉・溶鋼処理に抢ける反応特性

\section{2. スラグ-溶鉄間反応の熱力学}

このセッションでは, 加藤（早大）および萬谷（東北 大）を座長としてソーダ系, 石灰系の基礎スラグの熱力 学拈よびスラグ-溶鉄間反応の平衡論的基礎研究につい ていずれも大学側よりの発表が行われた。

ソーダ系スラグについては, まず後藤（東工大）は $\beta$ $\mathrm{Al}_{2} \mathrm{O}_{3}$ 固体電解質を用いた起電力法により液体 $\mathrm{Na}_{2} \mathrm{O}-$ $\mathrm{SiO}_{2}$ 系, $\mathrm{Na}_{2} \mathrm{O}-\mathrm{P}_{2} \mathrm{O}_{5}$ 系, $\mathrm{Na}_{2} \mathrm{O}-\mathrm{SiO}_{2}-\mathrm{P}_{2} \mathrm{O}_{5}$ 系の $\mathrm{Na}_{2} \mathrm{O}$ の活量を測定し,さらに他成分の活量を計算した結果を 報告した，質疑において，3元系の各成分の等活量線の 精度について質問があり， $\mathrm{SiO}_{2}, \mathrm{P}_{2} \mathrm{O}_{5}$ の活量は GiBBsDUHEM の式の積分によるもので精度がおちるといら答 えがあつた.ついで佐野（東大）は溶銑処理用ソーダ系 スラグの熱力学と題し, $\mathrm{Na}_{2} \mathrm{O}-\mathrm{SiO}_{2}$ 系融体の $\mathrm{Na}_{2} \mathrm{O}$ の 活量を化学平衡法により高塩基性領域について測定した 研究を報告した。この実験においては系内に $\mathrm{Pb}-\mathrm{Na}$ 合 金をいれ，Na ポテンシャルを制御するといら巧妙な手 法を導入した。 また $\mathrm{Na}_{2} \mathrm{O}-\mathrm{SiO}_{2}$ 系融体一の窒素の溶解 度を調べた、以上二つの研究は, わが国において炭酸り
一ダによる溶銑の脱りん法が央用化され， $\mathrm{Na}_{2} \mathrm{O}$ を含を スラグの熱力学的性質が実際的にも重要であるといらこ とが動機となつて本格的な基礎研究として取りあげられ たものである。

ついで萬行（東北大）は, 酸化鉄を含むスラグの活量 測定の結果および $\mathrm{Fe}_{t} \mathrm{O}-\mathrm{M}_{X} \mathrm{O}_{Y} 2$ 元系, $\mathrm{Fe}_{t} \mathrm{O}-\mathrm{SiO}_{2}-$ $\mathrm{MO} 3$ 元系, $\mathrm{Fe}_{t} \mathrm{O}-\mathrm{SiO}_{2}-\mathrm{MnO}-(\mathrm{CaO})$ 系, $\mathrm{Fe}_{t} \mathrm{O}-$ $\mathrm{P}_{2} \mathrm{O}_{5}-\mathrm{MO}$ 系, $\mathrm{Fe}_{t} \mathrm{O}$ の他に $\mathrm{Na}_{2} \mathrm{O}$ を含む系など各種 スラグの活量を正則溶液モデルで表示した多年の研究結 果を総括的に述べた。討論において, complex anion あるいは polymer であるスラグに対して正則溶液モデ 几を適用した点で先先性のあることが指摘され，さらに この事実と表傋をなす形で, cation の anion に対する 影響の optical basicity による評洒があることが述べら

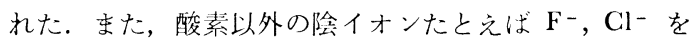
含むような系については別の理論が必要であることが指 摘され, さらに, 萬谷の研究したスラグ成分の活量の表 示法の呼び方についての新しい提案もなされた.

石灭系スラグの熱力学として, 原(服大)は, $\mathrm{Fe}_{2} \mathrm{O}_{3}=$ $2 \mathrm{FeO}+1 / 2 \mathrm{O}_{2}$ の反応を利用して試料の質量変化からス ラグの組成と平衡酸素分压の関係を求めるといら手法に より $\mathrm{FeO}-\mathrm{Fe}_{2} \mathrm{O}_{3}-\mathrm{CaO}$ 系の融体の $1550^{\circ} \mathrm{C}$ における等 酸素分生線図を求めた結果を述べた，また一瀬（京大） は，溶銑脱りん用石灰系フラックスの熱力学といら演題 で, 固体電解質を利用した起電力法による, 純鉄と平衡 する酸化鉄含有スラグの酸素分圧の測定法を確立させ, これにより $\mathrm{Fe}_{X} \mathrm{O}-\mathrm{CaO}-\mathrm{CaF}_{2}$ スラグおよび $\mathrm{Fe}_{X} \mathrm{O}$ $\mathrm{CaO}-\mathrm{CaCl}_{2}$ スラグの酸化鉄活量を測定するとともに, 実際の溶銑脱りん処理最終段階のスラグの酸化鉄活量 さらには $\mathrm{P}_{2} \mathrm{O}_{5}$ の活量測定も行つた. 加藤（早大）はク ヌーセンセル質量分析法を用いてスラグ中の $\mathrm{P}_{2} \mathrm{O}_{5}$ の活 量を測定する研究を行つたが, まず測定法の妥当性を $\mathrm{PbO}-\mathrm{P}_{2} \mathrm{O}_{5}$ 系について検討した後 $\mathrm{Fe}_{t} \mathrm{O}-\mathrm{P}_{2} \mathrm{O}_{5}$ 系の $\mathrm{P}_{2} \mathrm{O}_{5}$ の活量の測定を $1370 \sim 1390^{\circ} \mathrm{C}$ で行つた。この報告に 対し $a_{\mathrm{P}_{2} \mathrm{O}_{5}}$ の温度依存性について質疑心答が行われた。

水渡（東北大）は，製鋼酸化反応の平衡について基礎 データを得るため, $\mathrm{MgO}$ 飽和 $\mathrm{CaO}-\mathrm{Fe}_{t} \mathrm{O}-\mathrm{SiO}_{2}\left(-\mathrm{CaF}_{2}\right.$ $(1 \sim 4 \%))$ 系スラグ-溶鉄間の $\mathrm{P}, \mathrm{S}, \mathrm{Mn}, \mathrm{O}$ の分配平 衡の実験を行つた。このうち $\mathrm{P}$ 平衡については従来の Balajiva ら, Healy, Turkdogan らの式を再検討し, 新しい式を求め実験データの適用性について従来の式と 比較した。 また capacity の概念を導入して $\mathrm{P}, \mathrm{S}, \mathrm{Mn}$ 分配比と酸素ポテンシャル，スラグ組成の関係を求め た.

以上の第 1 セッションの発表の総合討論は後藤（東工 大）を座長としてすすめられた。この中で，水渡の研究 に関して実操業のデータとの差について討論があつた。 水渡が答えたように, 実際のデータが平衡洷到達してい ればそれは分配平衡の式に合うはずで，逆にみれば現場 
のデータが平衡にあるかどうかは平衡式で判定でき，こ こからまた速度論的娭刲一のきつかけがでてくる，水渡 の求めた結果をもつと現埸のデータの検封に使つたほう がよいのではないかといら発言があつた。

ソーダ系スラグについては, 現場では酸化鉄, 酸素を 使つており, 非平衡状態で反応が進んでいるが, この場 合酸素ポテンシャルがどの程度か，また何が酸素ポテン シャルを決定しているのかが問題で, この辺がどらもは つきりしないことが述べられた。

転炬スラグの酸化鉄の 2 洒, 3 洒の Fe の分析精度に ついて質され，粒鉄の分離，水分の影響についての留 意, 湿式分析法についての説明が大学側よりなされた. また $a_{\mathrm{P}}$ に対するCの影響について， SCHENCK のデ 一タは $e_{\mathrm{P}}^{\mathrm{C}}$ がかなり大きいことが指摘された。これは SCHENCK のデータはP 濃度がかなり高いところであ り，基準のとり方に問題があるとの説明がなされた。

松下 (東大名誉) は今後の研究の進む方向を大きく展 望し，い末までの理想化された状態の研究をもとにし て, 実際の状態をとりいれた条件下での研究を推し進め ることを要望した。ささのソーダ系スラグについての問 題提起でも感じられたが，理想化された条件下でのスラ グの熱力学, 平衡についての確実な知識が得られたわけ で,このことが今後垷場の現象を解明してゆく場合のゆ るぎない土台を与えるものと考えられる.

\section{3. スラグ-溶鉄間反応の速度論}

このセッションでは荻野（攺大）と森（名大）が座長 となり, スラグーメタル間反伈系の速度論的問題, とく に反応系の物質移動や浴内の流動, 攪拌について基礎的 立場からの発表討論を行つた。

森（九大）は, $\mathrm{CaO}-\mathrm{CaF}_{2}-\mathrm{Al}_{2} \mathrm{O}_{3}$ 系スラグによる溶 鉄の脱りん速度について発表し，脱りん速度が溶鉄，ス ラグ中の物質移動過程で文配されるとして説明できるこ とを示した. また本スラグによる溶鉄の同時脱りん脱硫 が可能であることを実験的に明らかにし，それについて の理論的基礎つけを行つた，そのほか $\mathrm{CaF}_{2}$ が脱りん 能, 脱り几速度をともに大きくすることを明らかにし た。

森（名大）は，溶銅中 $\mathrm{Si}$ の $\mathrm{Li}_{2} \mathrm{O}-\mathrm{SiO}_{2}-\mathrm{Al}_{2} \mathrm{O}_{3}$ スラ グ中 $\mathrm{FeO}$ による酸化反忘の速度論的実験を行い, 物質 移動の機構を明確にし，本反応系をスラグー溶融金属間 反応速度と挸汼の関係を検討するためのモデル反応系と して確立させた．ついで，この反応系を用い，物質移動 速度におよぼすガス吹込攪汼の影響を調べた。この研究 結果から，上下吹転炉内のスラグー溶鋼間の物質移動が 説明できるかどらか質されたが，これに答えるためには さらに多くの研究が必要であることが述べられた.

菊池（東北大）は精錬装置内のガス吹き込及による溶 鉄の攪拌特性を明確にするため，水モデルによる浴内の
流動状態を観察するとともに気泡分散モデルルより流速 分布およびガスホールドアッフ分布の数值解を得た。 た $\mathrm{CO}_{2}$-水系により気液間の容量係数や系内のガスホー ルドアップ分布を測定した．理論解析で用いた乱流粘性 係数を広範国な条件で求めることが今後の課題であると 述べた。

佐野（名大）は容器底部のオリフィスから水銀中一の ガス吹込実験を行い，ガスの分散挙動を電父探針法によ り調べた。また巨視的物質・運動量収支をとり気液混相 領域の流動解析を行い, 実験結果との比較検討を行つ た。従来, 液体中へのガス吹き远みに伴ら気液混相领域 中の諸現象に関する研究は非常に少ないため,この方面 の実験的理論的研究は今後さらに進める必要があること を述べた。

福沢 (金材研) は, 直接還元ベレットの連続溶解還元 炉における溶解還元特性を把握するための試験を行い, 還元ペレットの金属化率が低下するほど電力利用効率が 高く, その理由として CO 発生による浴内の攪汼が強 化され，これにより伝熱と反応の促進がもたらされたこ とをあげた。

小川（神鋼）は，取鍋精錬炉内の混合とスラグーメタ ル間反応特性を検討するためガス攪拌，誘導攪䢁および 粉体吹込攪汼を対象として水モデル実験を行い, 浴内混 合攪找挙動を均一混合時間で表した. ついでやはり常温 のモデルによりスラグーメタル間物質移動係数を求め, その值を攪找と関係つけるとともに，この結果が取鍋精 錬反心の物質移動に適用できることを示した．小川は， この研究を通じスラグーメタル間物質移動において液 表 面近傍での乱流変動速度が重要な因子であることを明ら かにした.

以上の発表の後, 森 (名大) が座長となり総合討論を 行つたが，この中で浴の攪拌を中心として興味哚い意見 交換があつた。 まず，精鍊炉内の攪拌と反応特性の関係 を表すのによく用いられる攪汼ェネルギー, 均一混合時 間の物理的意味は何かといらことである。これは流体内 の流動現象に関するものであり，たとえば添加合金の浴 内への均一溶解を表す場合とか, 浴内の dead space が 反応の進行に重要な意味をもつ場合のように, 現象をマ ク口的に把握するのには有効である。 しかし, 反応特性 との関係を求める場合には，攪拌エネルギーの概念にと らわれず, フローパターン, 局部物質移動などの観点か ら現象を局所的に把握する必要がある. 反応が, ガスーメ タル間の反応か, スラグーメタル間の反応かで攪拌 エネ ルギーの意味が異なる. 反応系の物質移動は, 理論的に は物質移動係数と接触面積の二つに分けて考察すべき でとくにスラグーメタル系では滴の形成が重要な意味 をもつ．またややアカデミックな立場からであるが，ガ スーメタル，スラグーメタル間反応系の反応式を明確にす る必要があり, 脱硫, 脱りんの問題でも一つの反応のみ 
でなく, 複合反応の可能性や他の異相間反応との関連も 問題にすべきではないかといら発言があつた.

LD 転炉内で低炭素領域で浴内攪拌が弱い問題がとり あげられ，この問題の議論の中で，浴内の攪拌が弱いこ とがガスーメタル分散相の姿にどのように現れているか に力点のある見方と䚌汼が弱いため C 濃度が不均一であ り，これが浴全体の流動とどのよらな関係があるかの見 方が出された。この両者をまとめた見方をもら少し進め たところで技術的アクションが何か生れるのではないか と感じた。

このセッションでの討論で最も注目すべき問題が井上 (名大名誉)により提起された。「反応特性, 液の流動パ ターンからみて最適形状の容器はどのようなものか?」 これについて，スラグーメタル反応であれば界面に乱れ をつくるものであること，浴内に dead space のない形 状であることなど発言があつたが，大学側と企業側の両 者について今後研究を進めてゆくべき方向をきびしく指 摘された思いであつた。

\section{4. 溶銑処理における反応特性}

この部門は融体精錬反応部会においてもつとも活発な 発表討論が行われ，シンポジウムでも多くの発表があつ た。座長は佐野（東大）と松永（新日鉄）がつとめた。

セッションのはじめに，江見（川鉄）は製鋼プロセス に抢ける不純物低減の必要性として, 極低濃度域におよ ぶ不純物濃度と鋼特性の関係についての最近の研究をま とめ, またその極低濃度を実現させる鋼精鍊法を溶銑処 理法と取鍋精錬法について総説するとともに今後の発展 の方向を示した.

丸川（住金）はソーダ系フラックスによる溶銑処理に おける治金反応特性につき基礎実験および実操業の結果 を報告した。この中で，ソーダ灰添加による $\mathrm{P}, \mathrm{S}, \mathrm{Mn}$, $\mathrm{V}$ の反応挙動，効率的脱りんのために $[\mathrm{Si}]<0.15 \%$ が 必要であること, 脱りん, 脱バナジウム反応の詳細, ソ ーダ系スラグの sulfide capacity, 酸素ポテンシャルを 述べ, 今後の溶銑予備処理全体の課題を示した。

原島（新日鉄）は $\mathrm{CaF}_{2}, \mathrm{CaCl}_{2}$ を含有する $\mathrm{CaO}$ 系 フラックスによる $1 \mathrm{~kg}$ の溶銑処理の研究を報告した。 スラグーメタル間のりん分配比 $L_{\mathrm{P}}$ と硫黄分配比 $L_{\mathrm{S}}$ はス ラグ塩基度 $B\left(\equiv N_{\mathrm{CaO}} /\left[2 N_{\mathrm{SiO}_{2}}+3 N_{\mathrm{P}_{2} \mathrm{O}_{5}}\right]\right)$ でよく整理 できる，添加剤は $L_{\mathrm{P}}$ を増加させ，その順位は $\mathrm{CaCl}_{2}>$ $\mathrm{CaF}_{2}-\mathrm{CaCl}_{2}>\mathrm{CaF}_{2}$ である. $L_{\mathrm{S}}$ は添加剂の増加ととも にわずかに減少する。その程度は添加剤の種類にあまり 依存しない。

中島（日新）はソーダ扊による溶銑の脱りんにおいて は上吹投射と底吹きインジェクションで反応挙動が異な

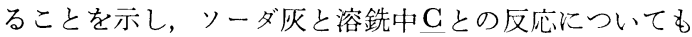
検討した。 また， $\mathrm{O}_{2}$ 富化キャりヤガスを用いた $\mathrm{CaO}$ 系フラックスインジェクションによる脱りんでは融剂と
して $\mathrm{CaF}_{2}$ がすぐれていること，吹き込まれた全酸素の みにより支配されて脱りん度応が進行することを示し た。

中村 (鋼管) は，小型基礎実験により $\mathrm{CaO}-\mathrm{CaF}_{2}$ 系 スラグによる溶銑の脱りん反㐫について速度論的検討を 加之，脱りん反心では $\mathrm{FeO}$ による酸素の反応界面への 供給が律速となつていることを推定した。また㬰機試験 でも基礎実験と同じく脱りん挙動はスラグの $\mathrm{FeO}$ 濃度 の変化で説明できることが示された。

尾上（神鋼）は，石庅系フラックスインジェクション による溶銑予備処理における精錬挙動について基礎なら びに $15 \mathrm{t}$ 規模での実験結果を述べた。このうち, 脱球 処理については各種方式を比較し，また脱りん脱硫につ いては転炉型容器を用い $\mathrm{CaO}-\mathrm{CaF}_{2}-\mathrm{Fe}_{2} \mathrm{O}_{3}-\mathrm{Na}_{2} \mathrm{CO}_{3}$ 系 フラックス吹込み・酸素吹精により効率のよい結果が得 られたことを述べた。

野崎（川鉄）は，底吹転炉，溶銑装入鍋，トーピード 車の各反応容器を用いて行つた溶銑脱りん実験について の結果を総括的に述べ，この中でとくに底吹転炉による 脱りんについて溶銑試料から検出したスラグ粒の組成分 析に裏付けされた新しい反応モデルを提出した。また装 入鍋を用いた実験では酸素プローブによる $P_{\mathrm{O}_{2}}$ の測定 を行い，脱りんと脱硫が別々な反忘サイトで行われるこ とを述べた。浴を浮上してきたスラグが浴表面でどらな るかについて質問が出たが，理論的にはこの浮上後のス ラグの挙動の解明が興味ある今後の課題とらけとれた。

山田 (鋼管) は高炉鋳床で溶銑流にフラックスをイン ジェションすることにより脱珄脱りんを行う方法につ き実験し，この方法が脱琒のみでなく脱りんに対しても 反応を非常に促進させることを示すとともに，速度論的 解析により，自然落下によるフラックス添加法に比べ物 質移動の容量係数が約 2 桁大きくなることを明らかにし た.この発表について, フラックスの粒徍, 滞留時間, プロセスの制御等についての質疑が出された.

以上の発表について丸川（住金）の座長のもとで総合 討論が行われたが，その要点を以下に記す。

石灰系フラックスの脱りん能について，原島ら（新日 鉄）の結果によれば $\mathrm{CaF}_{2}$ より $\mathrm{CaCl}_{2}$ の方がよいこと が示されているが，佐野ら（東大）の平衡論的研究では 同一酸素ポテンシャルのもとでは $\mathrm{CaF}_{2}$ を $\mathrm{CaCl}_{2}$ で置 換するとりん分配比が低下するという逆の結果がでてい る.これは平衡論的数值が実際の反応にそのまま現れて いないわけで，この問題をめぐつての討論には興味深い ものがあつた。原島は大気下の実験で反応界面の酸素ホ テンシャルが添加剤によつて変化しているためと考兄て いると答え, 佐野は熱力学的には $\mathrm{CaF}_{2}$ 系の方が $\mathrm{CaCl}_{2}$ 系よりも塩基性の性質が強く，このことは $\mathrm{CO}_{2}$ の溶解 度の測定からも明らかにされていることで，実際の場合 には $\mathrm{CaCl}_{2}$ を添加するとスラグの流動性が大となりこ 
れが速度論的に反応性をよくするのではないかと述べ た。こ机対し中島ら（日新）の研究では $\mathrm{CaF}_{2}$ の注う が脱りんがよくなつているが，中島はこれについて理由 はよくわからないと述へ，またこれは $\left(\mathrm{CaF}_{2}\right.$ の場合界 面の $P_{\mathrm{O}_{2}}$ が高いのではないかとの問いに） $P_{\mathrm{O}_{2}}$ の問題 でもないと述べた。

山田ら (鋼管)の鋳休での溶銑処理の研究についても 活発な質疑応答が行われた。鋳床脱りんが熱力学的にみ れば高温で不利であり，このことを $P_{\mathrm{O}_{2}}$ が補つていると 述べているが，これは粉体が浮上する途中で应応が進行 していることからでてくることが示された．処理後のス ラグの $\mathrm{FeO}$ が 10\% と高いのは, 現状では滞留時間が短 いためでありここの点は脱硫との関係から別の問題を生 さ. 鋳床処理で温度が高いが，脱炭量は $0.2 \sim 0.3 \%$ で ある. 溶銑 $\mathrm{Si}$, 温度, 出銑速度の変動に対しての脱珪の 制御方式については，Si 分析計やロードセルなどの使 用が検討されている。 また処理開始後の潜伏時間 (incubation time) については, この時間は $2 \sim 3 \mathrm{~min}$ で, この間の溶銑星は 10〜15 t であることが述べられた。

脱りんと適正な䚓拌の関係についての問題がとりあげ られた，山田ら (鋼管) の研究によれば、ソーダ灰を鍋 にいれガス攪拌をした場合 $3 \mathrm{Nm}^{3} / \mathrm{min}$ が最大の脱りん を与えたが，石圧系処理では $4 \mathrm{Nm}^{3} / \mathrm{min}$ がもつともよ

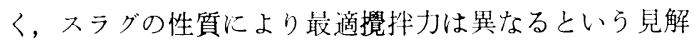
が示された。

座長丸川は，脱りん成応が部会の中心テーマの一つで あり多くの研究を行つてきたがと前置きし，溶銑処理の 方式, 反応の解析, ソーダ系と石灭系の比較などについ て, 熱力学, 速度論, プロセス工学的観点にたつた大学 側からのコメントを求めた。これについてつぎのよらな 見解が出された，脱りんだけをみると酸素を過㮃に加兄 ていることはないのか, $\mathrm{FeO}$ の供給に問題はないのか, 酸化鉄はスラグの塩基度を下げるので脱りんからみての $\mathrm{FeO}$ の最適な濃度がどこかにある。溶銑では $\mathrm{FeO} 2 \sim$ $3 \%$ でも脱りんが進行するが，これが可能であるのは塩 基度の点からみるとむしろ $\mathrm{FeO}$ を下げた状態で脱りん していることにも一つの原因がある。プロセス工学的観 点から, マクロな現象のとら方，とくに物質収支につ いての記述が少なく, この点の把握が非常に重要なので はないか, フラックスの鋼浴中での滞留時間や反応進行 の場所および各場所で捄こる反応の区別についての検討 をさらに進めていくことが必要ではないか，またインジ ェクションの役割が必ずしも明確でない，などの意見が 出された。ささらに企業側から， Si, P 同時反応の進行や 復りん反心（おそい）の律速段階，反応の場所に打ける 酸素ポテンシャル，フラックスの最適な添加方法など多 くの問題が末解決のままに残されていることが述べられ た.

\section{5． 転炉・溶鋼処理における反応特性}

最後のセッションは野崎（川鉄）の座長のもとで, 転 炬 1 件, 溶鋼処理 4 件の発表が行われた.

大河平（新日鉄）は，上底吹転炉の脱り几反応特性を LD 転炉, 上底吹転炉の操業データにもとづいて解析し た結果を報告した。それによれば，1）活量を用いた脱 りん平衡值からみて，低炭素領域に沶いて底吹きの併用 により脱りん反応が平衡により接近するといら傾向はと くに認められないこと，2) 上底吹転炑で低い(\% $\mathrm{Fe})$ で脱りんが可能になるのは $(\% \mathrm{CaO})$ が上昇して $\gamma_{\mathrm{P}_{2} \mathrm{O}_{5}}$ が低下寸る，つまりスラグの脱りん能が高まることによ るものであるとの考觉が示された。この研究において $\mathrm{Fe}^{3+}$ の存在が $a_{\mathrm{Fe}_{t} \mathrm{O}}$ にどのように影響するかの質問 が出たが，少なくとも精鍊末期においては $\mathrm{Fe}^{3+}$ は少な くなつているのであまり考光る必要がないとのコメント があつた。 また底吹きの併用がスラグの上熱の解消によ り脱りん分配の改善をもたらす可能性が問われ，大河平 は，最近の測定から上吹転炉の上熱はあまり大きくな く，熱伝導度を考慮すると底吹きの併用によるスラグ上 熱の解消効果は脱りん反応にはあまり顕著には現れない と考えていると述べた.

池田（大同）は，酸化脱りん法としてッーダ灰系フラ ックスを，また還元脱りん法として $\mathrm{CaC}_{2}$ 系フラック スを対象に脱りん試験研究を行つた．前者については, りん分配比がンーダ乍上置法に比べ吹き込文法の方が大 きいことを確かめた，後者については， $\mathrm{CaC}_{2}-\mathrm{CaF}_{2}$ お よび $\mathrm{CaCN}_{2}$ フラックスによる脱りんを行い, $\mathrm{CaCN}_{2}$ でも脱りんは可能であつたが, $\mathrm{N}_{2}$ 発生により $\mathrm{Ca}$ 蒸 発, $\mathrm{Ca}-\mathrm{N}$ 反応が生じ脱りん率が低かつた。

松尾 (住金) は, ステンレス粗溶鋼の脱りんについ て, 高塩基性で弱い酸化力をもつ $\mathrm{BaO}-\mathrm{BaCl}_{2}-\mathrm{Cr}_{2} \mathrm{O}_{3}$ フ ラックスを用いた脱りんをるつぼ実験と $10 \mathrm{t} \mathrm{AOD}$ 炉 実験で研究した。AOD 炉の実験では強筧挥のためか Cr が 25\% と高くなつても脱りん率はあまり低下しな い.フラックスとしては, $\mathrm{BaO}$ は同じ $\mathrm{Ba}$ の塩化物や ふつ化物と組合せる必要がある. 冷却スラグについてP の化合物の同定から, 酸化脱りんが行われ, $\mathrm{Cl}$ もこの 反応に寄与した可能性が示された. 質疑応答の中で, フ ラックスの再生について, 処理後の成分は $\mathrm{BaO}-\mathrm{BaCl}_{\mathbf{2}}-$ $\mathrm{Cr}_{2} \mathrm{O}_{3}-\mathrm{P}_{2} \mathrm{O}_{5}$ で，これを $\mathrm{C}$ 還元すると融点の低い $\mathrm{BaO}-$ $\mathrm{BaCl}_{2}$ に再生できることが述べられた。 また処理時の温 度低下は約 $100^{\circ} \mathrm{C}$ で, 除涬は手作業で完全にでき, 復 りんは $0.001 〜 0.002 \%$ であつた。 また脱珪は電気炉と AOD の間で行い, そのコントロールは経験できめてい る.

還元脱りんに関しては 2 件の発表が行われた。片山 (新日鉄) は, $\mathrm{CaC}_{2}-\mathrm{CaF}_{2}$ 系フラックスによる $\mathrm{Fe}-\mathrm{Cr}$ $\mathrm{C}, \mathrm{Fe}-\mathrm{Mn}-\mathrm{C}$ 系合金の脱りんの処理条件と脱りん挙動 
を研究した．合金のCの活量が小さい汪ど（Ca)の生成 が多く脱り几率が大きい，脱り几率が変動する要因の一 つとして $\mathrm{Ca}$ 蒸発量の差があり, $1480^{\circ} \mathrm{C}$ 付近の温度で 最大の脱りん率が示された。基礎試験にもとづき実機規 模においてはフラックスインジェクション法が有効な処 理手段であることを推定した．処理後のスラグからのフ オスフィンガス $\left(\mathrm{PH}_{3}\right)$ の発生対策として, 溶融状態に おいて酸化剤をスラグに添加して安定な $\mathrm{P}_{2} \mathrm{O}_{5}$ に変質さ せる方法を述べた。

竹之内 (日鋼) は, $\mathrm{Ca}, \mathrm{CaC}_{2}$ による高クロム鋼の精 錬について報告した．Ca による脱りんは 1360１550 ${ }^{\circ} \mathrm{C}$ で低温ほど有利である。 $46 \% \mathrm{Cr}-1 \% \mathrm{C}$ 溶鋼の $\mathrm{CaC}_{2}$ による脱りんでは， $1500 \sim 1600^{\circ} \mathrm{C}$ の間で高温泣ど $\mathrm{CaC}_{2}$ の分解が促進されて $\mathrm{P}$ の減少就よび $\mathrm{C}$ の增加が はやいことがわかつた，Caによる最適脱りん条件は $45 \% \mathrm{Cr}$ では $\mathrm{C} 3 \%$ 前後であり, $\mathrm{CaC}_{2}$ 脱りんでは $a_{\mathrm{C}}$ $=0.02 \sim 0.3$ の範囲である. 工業化試験としては酸化脱 りんを行つた炭素鋼と還元脱りんを行つた高クロム鋼の 両者を混合するDuplex 法について試験した。

総合討論は川上（鋼管）を座長として行われた。 川上 は今後わが国の製鋼技術がより高付加価值製品の製造に 進劣と考兄られ，この点で含クロム鋼の脱りんは重要な 要素技術になるとしてこの分野の研究の意義を明らかに した。佐野（東大）は基礎的観点からつぎのような意見 を述べた。 まず，反応についての熱力学的な測定值の信 頼できるデータが章しいことを指摘した． $\mathrm{Ca}_{3} \mathrm{P}_{2}$ の生成 自由エネルギーの正確な值はなく，その他トランプエレ メント As, Zn, Sb などについてもなく, この方面の 基礎研究の必要性がある。酸化脱りんに比較し還元脱り んのデータは非常に少ない，酸化脱りんについて， $\mathrm{BaO}$ や $\mathrm{Li}_{2} \mathrm{CO}_{3}$ などより強い塩基性のフラックスによる脱り んの試験が行われつつありそれはも方万ん有意義ではあ るが，他にもたとえばソーダ系と $\mathrm{CaO}$ 系にわけないで 一緒にしたフラックスについても追求する必要がある. 一方実際的立場から，野崎(川鉄) は溶銑処理で徹底的に 脱りんした溶銑を用いること，また高 $\mathrm{Cr}$ 鋼脱りんは熱 力学的計算に上ると $\mathrm{CaO}$ 系に若干の媒溶剤の添加でで きる可能性があることを述べた，尾上(神鋼) は, $\mathrm{BaCO}_{3}$ 系フラックスあるいは $\mathrm{BaO}-\mathrm{BaCl}_{2}$ をCでューティン
グしたフラックスを脱りん剂として用いていると述べ た，高橋（鋼管）は種々の媒溶剂を用いたライムー・ー ダ系フラックスによる含クロム鋼脱りんを試験中である ことを説明した。

このように各社とも浴鋼の脱りんとくに含クロム鋼な ど合金鋼の脱りんに深い関心をもつていることが示され た。還元脱りんの比較検封，還元脱りんに拈りる $a_{\mathrm{c}}$ の 役割り, 処理温度の影響, $P_{\mathrm{O}_{2}}$, スラグ中 $(\mathbf{C a})$ の挙 動，塩基度の影響およびスラグ処理など個々のテーマに 関する討論は時間がなくて実施されなかつた。しかし， 鋼の超高純度処理や鉄鋼の高付加佂值化がわが国製鋼技 術の大きな特色となりつつあるとき，今後の研究課題と しての合金鋼の脱りんに関する講演とコメントが行われ たことは大変意義深いものであつた。

\section{6.おわりに}

以上のとおり，製鋼におけるスラグー溶鉄間反応につ いて平衡論, 速度論, ブロセ入下学の幅伀い観点からの 発表討論を行い，解明されたこと，末解明の事柄，今後 の問題点が明らかになり，有意義なシンボジゥムをもつ ことができた。部会の研究課題として重点をおいたりー ダ系，石灰系スラグの脱りん反伈性については，熱力学 的平衡論的研究や実際的観点からの研究で多くの成果が 得られた。スラグースタル間の物質移動や攪汼の問題も とり亦げられ解明が進んできた．今後の課題として平衡 論的数值については引き続き測定研究を進めてゆく必要 がある. 浴内の㩭找, 流動現象, 筧拌の反応速度や反応 特性に及注す影響を基礎的にさらに深く堀り下げる研究 は残された重要課題の一つである。一・方，大学を中心と した基礎研究として従来の半衡詇に!:体を拈いた物理化 学的研究とならび, 移動速度論をとりいれたブロセ大工 学的研究をさらに発银させる必裂がある。

本稿をまとわるにあたり、シン卡ジウムの座長, 講演 者，討論者からのメモ書きを参考にさせていただいた。 とくに第 5 章は日本鋼管(株)川上公成氏によるまとるを 若干加筆修正したものである。李た名古屋大学佐野正道 助教授からはンンボジウムの準備, 記録, 本稿の執筆に 全面的な協力を得た。これらの方々に深い感謝の意を表 し守市。 